ISSN: 2362-1303 (Paper) | eISSN: 2362-1311(Online)

JOURNAL OF ADVANCED ACADEMIC RESEARCH (JAAR)

January 2015

\title{
Respondents wise Status of Non-Governmental Organizations (NGOs) of Karnali Zone Nepal
}

\section{Kushendra Bahadur Mahat ${ }^{1}$ \& Prof. Dr. Bihari Binod Pokharel ${ }^{2}$}

${ }^{1}$ PhD Scholar, Dr. K. N. Modi University, Newai, Rajasthan, India

2 Director, Master of Business Management Program, Nepal Commerce Campus, Tribhuwan University, Minbhawan, Kathmandu, Nepal

\section{Corresponding Author}

Kushendra Bahadur Mahat

Email: k6mahatg@gmail.com

\begin{abstract}
Non-Governmental Organizations (NGOs) have been promoted in the development activities in Nepal since the restoration of democracy in 1990. NGOs have been recognized as one of the development facilitator institutions in Karnali Zone. The objective of this study was focused to identify the status of Non-Governmental Organizations (NGOs) on the basis of its structure, environment, values and Impact. The study had adopted the civil society index as a theoretical tool of study. Randomly in total 562 respondents were selected from five districts of Karnali zone. The findings of ANOVA showed that there was a significant difference between respondents in the structure of NGOs in P=0.007 significant level at $95 \%$ confidence interval. But other three components environment, values and impact were not significantly difference. It could be assumed that because of the geographical differences, involvement of human resources, basic infrastructure, access on communication and technologies and perception on NGOs activities are the major factors which made the perceptual difference among the respondents in structure of NGOs. Similarly, contribution of NGO in promotion of political awareness, transparency of their work and empowering citizenship were more or less in the same level in all five districts so response of participants became similar in environment, values and impact of NGOs. It is necessary to identify the locally reliable and related indicators of NGO to assess the $N G O$ 's status and their performance.
\end{abstract}

Keywords: NGO, Respondents, Status, 
ISSN: 2362-1303 (Paper) | eISSN: 2362-1311(Online)

JOURNAL OF ADVANCED ACADEMIC RESEARCH (JAAR)

January 2015

\section{Introduction}

The study was focused to identify the status of Non-Governmental Organizations (NGOs) on the basis of its structure, environment, values and Impact. This study was carried out in five districts; Dolpa, Humla, Jumla, Kalikot and Mugu of Karnali Zone. Karnali Zone falls under the lowest ranking among all zones and districts of Nepalfrom the Human Development Index (HDI). In this context, NGOs were played significant contribution to meet the minimum basic needS of the community along with Nepal Government. There were 32000 NGOs registered and affiliated with Social Welfare Council which 560 NGO in Karnali Zone. NGOs in Nepal formed and operate under the Societies Registration Act 2034 (1977) and Social Welfare Act 2044. District Administration Office (DAO) and the Social Welfare Council (SWC) are the important governing institutions of NGOs in Nepal (Dhakal, 2007, p. 5). NGOs HAVE been working on the environment sector, forestry sector, wildlife sector and national development; poverty, human right, HIV and AIDS, health, etc. (Bhandari, 2014, p. 183). Since the 1990s, the role of development non-governmental organisations (NGOs) in international development has increased along with massive interest and concern over NGO performance from NGO practitioners, governments, citizens, donors, policymakers and academics (Lund, 2012). The current main crux of the matter in Nepal is how to reach out to the most excluded and needy people for their improvements. Both donors and NGOs apply different approaches to this issue; some INGOs go as far as contracting directly with local communities and user groups - by passing intermediary Nepali NGOs (Ingdal, 2007, p. iv). NGOs have been recognized as one of the development actors but formal academic research of the contributions and their status is not carried out in Karnali Zone. Civil society institution and NGOs in different sectors can bridge the differences between transitional citizens with different backgrounds as they learn to coexist in the public sphere and concomitantly develop higher levels of trust (Abom, 2004; TUSALEM, 2007, p. 380). To find the status of the NGOs in Karnali Zone, specific research was carried out with the basis of Civil Society Index (CSI).

\section{Method}

Quantitative designed was applied in the study. In quantitative data, cross-tab, frequency table and ANOVA test and multiple comparison (Bonferroni test) values were analyzed for descriptive analysis of data, as well as correlation was done to explore the relation between two and multiple variables. In total 562 respondents were selected from 5 groups: beneficiaries -400 , NGOs Board - 56, NGOs staff - 56, Civil Society - 25, Government Official - 25. In district wise, number of participation were Dolpa - 66, Humla - 82, Jumla - 146, Kalikot - 174 and Mugu - 94 by using the simple random sampling. Multistage Simple Random Sampling was used to deduct the size of the study area on the basis of logical reasoning and simple random sampling which was adopted to select the respondents. Under the random sampling, lottery method (two types of similar paper card was used having with symbol of ' 0 ' and '1' ('0' means not selected and '1' 
ISSN: 2362-1303 (Paper) | eISSN: 2362-1311(Online)

JOURNAL OF ADVANCED ACADEMIC RESEARCH (JAAR)

January 2015

means selected) was used to select the respondents for survey and interview both. The entire paper cards were kept in one container and participants were asked to draw the card. Who got the 1 , was selected for the study.

\section{Result}

This study had measured the main four elements (structure, environment, values, and impact) of NGOs on the basis of five types of respondents. These four elements determine the overall status of the NGOs and their performances. All these four elements also include 25 sub-elements. Under these 25 sub-elements there were 74 individual indicators which support to measure the NGOs. These sub-elements were as below:

\section{Structure}

There are six main components under the structure. These six components are breadth of citizen participation, depth of citizen participation, diversity of civil society participation, resources, level of organization and inter relation of NGOs. There is a significant difference between respondents in the structure. There is significant difference of breadth of citizen participation between civil society to beneficiaries, NGO board and Civil Society. There is significantly difference of depth of citizen participation between civil society and beneficiaries and NGO board. There is a significant difference of resources and interrelation between NGO boards, civil society and beneficiaries.

\section{$\underline{\text { Environment }}$}

There are seven main components under the environment. These seven components are political context, basic freedom of rights, socio-economic context, socio-cultural context, private sector civil society, legal environment and state civil society. There is no significantly difference between beneficiaries, NGO board, NGO staff, and Government and Civil society.

\section{$\underline{\text { Values }}$}

There are seven main components under values. These seven components are democracy, transparency, tolerance, non-violence, private sector civil society, poverty eradication and gender equity. There is no significantly difference of non-violence between respondents.

\section{$\underline{\text { Impact }}$}

There are five main components under Impact. These five components are holding state \& private sector, influencing public policy, responding to social interest, empowering citizens and building social capital. There is no significantly difference of non-violence between respondents. 
ISSN: 2362-1303 (Paper) | eISSN: 2362-1311(Online)

JOURNAL OF ADVANCED ACADEMIC RESEARCH (JAAR)

The study had collected the data from the respondents regarding their perception on status of NGOs of Karnali Zone on the basis of major four elements. The data presented below explained the mean value of each element of NGOs. The following data shows the mean differentiation of four major elements (structure, environment, values, and impact) on the basis of five types of respondents. The analysis of variance (ANOVA) test was calculated and found the following values. The mean values and value of f-test has given the description of NGOs status in Karnali Zone. Comparative data are presented to identify the high and low value of four main elements as well as its significant differences between and within the respondents.

Respondent wise mean value of four elements of NGOs

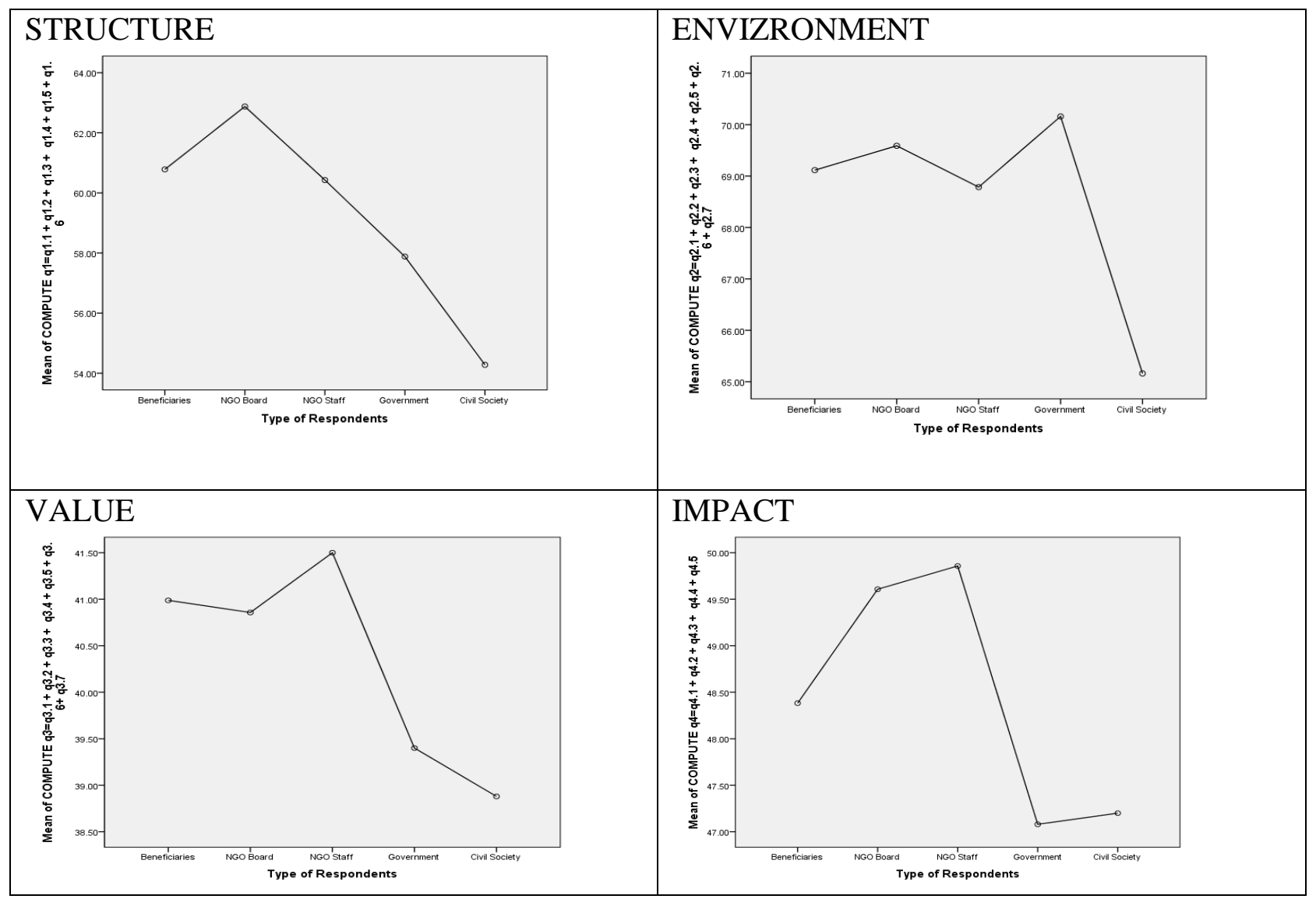

ANOVA test within the respondents

\begin{tabular}{|l|l|l|l|}
\hline Description & F Value & P - Values & Remarks \\
\hline Structure & 3.582 & 0.007 & Significant \\
\hline Environment & 0.941 & 0.44 & Insignificant \\
\hline
\end{tabular}


ISSN: 2362-1303 (Paper) | eISSN: 2362-1311(Online)

JOURNAL OF ADVANCED ACADEMIC RESEARCH (JAAR)

January 2015

\begin{tabular}{|l|l|l|l|}
\hline Values & 0.977 & 0.420 & Insignificant \\
\hline Impact & 0.829 & 0.507 & Insignificant \\
\hline
\end{tabular}

Source: Field survey, 2014

From the above table in the structure $\mathrm{F}$ value is 3.582 and P-values is .007 observed. It indicates there is a significant difference between respondents in the structure. And other three components environment, values and impact are not significantly difference observed within respondents. There was significant difference in structure among the types of respondents in $\mathrm{P}=$ .007 significant level at $95 \%$ confidence interval. But the data accepted was no difference in environment, values and impact among the types of respondents in $\mathrm{P}=.44, \mathrm{P}=0.420$ and $\mathrm{P}=$ 0.507 respectively significant level at $95 \%$ confidence interval.

Respondent wise multiple comparison of major elements of NGOs (Bonferroni test)

Table 1: Respondent wise multiple comparison of structure of NGOs

\begin{tabular}{|c|c|c|c|c|c|}
\hline \multirow{2}{*}{$\begin{array}{l}\text { Desc } \\
\text { ripti } \\
\text { on }\end{array}$} & \multirow{2}{*}{ Respondents types } & \multirow{2}{*}{$\begin{array}{l}\text { P- } \\
\text { Values }\end{array}$} & \multicolumn{2}{|c|}{$\begin{array}{l}95 \% \quad \text { confident } \\
\text { level }\end{array}$} & \multirow{2}{*}{ Remarks } \\
\hline & & & $\begin{array}{l}\text { Lower } \\
\text { bound }\end{array}$ & $\begin{array}{l}\text { Upper } \\
\text { bound }\end{array}$ & \\
\hline \multirow{10}{*}{ 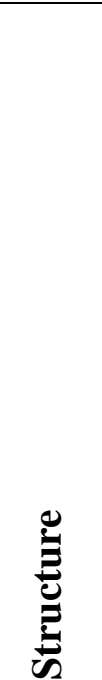 } & Beneficiaries - NGO board & 1.000 & -6.187 & 2.002 & No significant difference \\
\hline & Beneficiaries - NGO staff & 1.000 & -3.741 & 4.449 & No significant difference \\
\hline & Beneficiaries - Government & 1.000 & -3.014 & 8.819 & No significant difference \\
\hline & Beneficiaries - Civil society & 0.021 & 0.585 & 12.419 & $\begin{array}{ll}\text { Beneficiary } & \text { has } \\
\text { significantly higher } & \end{array}$ \\
\hline & NGO board - NGO staff & 1.000 & -2.977 & 7.870 & No significant difference \\
\hline & NGO board - Government & 0.419 & -1.908 & 11.898 & No significant difference \\
\hline & NGO board - Civil society & 0.005 & 1.691 & 15.498 & $\begin{array}{l}\text { NGO board has } \\
\text { significantly higher }\end{array}$ \\
\hline & NGO staff - Government & 1.000 & -4.355 & 9.452 & No significant difference \\
\hline & NGO staff - Civil society & 0.124 & -0.755 & 13.052 & No significant difference \\
\hline & Government - Civil society & 1.000 & -4.518 & 11.7183 & No significant difference \\
\hline
\end{tabular}

Source: Field survey, 2014

The table no. 1 shows that there was significant difference between the beneficiaries and civil society at the $\mathrm{P}=0.021$ significant level which is less than .05 . The value of beneficiaries was significantly higher than civil society. Similarly, there was significant difference between the NGO board and civil society at the $\mathrm{P}=0.005$ significant level which is less than .05 . The value of NGO board was significantly higher than civil society. 
ISSN: 2362-1303 (Paper) | eISSN: 2362-1311(Online)

JOURNAL OF ADVANCED ACADEMIC RESEARCH (JAAR)

The relation between the other respondents; government vs. civil society, NGO staff vs. civil society, NGO staff vs. government, beneficiaries vs. government, NGO board vs. NGO staff found no significant difference because the $\mathrm{P}$ value was greater than .05 significant level.

The above table and graphs shows that NGO board value has higher score and civil society has lower score between five respondents.

Table No. 2: Respondent wise multiple comparison of environment of NGOs

\begin{tabular}{|c|c|c|c|c|c|}
\hline \multirow{2}{*}{$\begin{array}{l}\text { De } \\
\text { scr } \\
\text { ipt } \\
\text { io } \\
\text { n }\end{array}$} & \multirow[b]{2}{*}{ Respondents types } & \multirow[b]{2}{*}{$\begin{array}{l}\text { P- } \\
\text { Value } \\
\text { s }\end{array}$} & \multicolumn{2}{|c|}{$\begin{array}{l}95 \% \text { confident } \\
\text { level }\end{array}$} & \multirow[b]{2}{*}{ Remarks } \\
\hline & & & $\begin{array}{l}\text { Lowe } \\
\mathbf{r} \\
\text { boun } \\
\text { d }\end{array}$ & $\begin{array}{l}\text { Upper } \\
\text { bound }\end{array}$ & \\
\hline \multirow{10}{*}{ 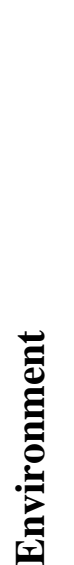 } & Beneficiaries - NGO board & 1.000 & -4.771 & 3.822 & No significant difference \\
\hline & Beneficiaries - NGO staff & 1.000 & -3.967 & 4.626 & No significant difference \\
\hline & Beneficiaries - Government & 1.000 & -7.253 & 5.163 & No significant difference \\
\hline & Beneficiaries - Civil society & 0.731 & -2.253 & 10.163 & No significant difference \\
\hline & NGO board - NGO staff & 1.000 & -4.887 & 6.494 & No significant difference \\
\hline & NGO board - Government & 1.000 & -7.814 & 6.673 & No significant difference \\
\hline & NGO board - Civil society & 0.854 & -2.814 & 11.673 & No significant difference \\
\hline & NGO staff - Government & 1.000 & -8.618 & 5.8696 & No significant difference \\
\hline & NGO staff - Civil society & 1.000 & -3.618 & 10.869 & No significant difference \\
\hline & Government - Civil society & 0.986 & -3.518 & 13.518 & No significant difference \\
\hline
\end{tabular}

Source: Field survey, 2014

The table no. 2 has explained the multiple comparisons between the respondents regarding their perception on environment of NGOs. The data shows that there was no significant differences between the each group of respondents because $\mathrm{P}$ value was found greater than $.05(5 \%)$ of significant level at $95 \%$ confidence interval.

Table no. 3: Respondent wise multiple comparison of values of NGOs

\begin{tabular}{|c|c|c|c|c|c|}
\hline \multirow{2}{*}{ Description } & \multirow{2}{*}{ Respondents types } & \multirow{2}{*}{$\begin{array}{l}\text { P- } \\
\text { Values }\end{array}$} & \multicolumn{2}{|c|}{$\begin{array}{l}95 \% \text { confident } \\
\text { level }\end{array}$} & \multirow{2}{*}{ Remarks } \\
\hline & & & $\begin{array}{l}\text { Lower } \\
\text { bound }\end{array}$ & $\begin{array}{l}\text { Upper } \\
\text { bound }\end{array}$ & \\
\hline \multirow{2}{*}{$\frac{\mathscr{e}}{\stackrel{\theta}{E}}$} & Beneficiaries - NGO board & 1.000 & -2.604 & 2.864 & $\begin{array}{ll}\text { No } & \text { significant } \\
\text { difference } & \end{array}$ \\
\hline & Beneficiaries - NGO staff & 1.000 & -3.247 & 2.222 & significant \\
\hline
\end{tabular}


ISSN: 2362-1303 (Paper) | eISSN: 2362-1311(Online)

JOURNAL OF ADVANCED ACADEMIC RESEARCH (JAAR)

January 2015

\begin{tabular}{|c|c|c|c|c|}
\hline & & & & difference \\
\hline Beneficiaries - Government & 1.000 & -2.363 & 5.538 & $\begin{array}{ll}\text { No } & \text { significant } \\
\text { difference } & \end{array}$ \\
\hline Beneficiaries - Civil society & 1.000 & -1.843 & 6.058 & $\begin{array}{ll}\text { No } & \text { significant } \\
\text { difference } & \end{array}$ \\
\hline NGO board - NGO staff & 1.000 & -4.264 & 2.979 & $\begin{array}{ll}\text { No } & \text { significant } \\
\text { difference } & \end{array}$ \\
\hline NGO board - Government & 1.000 & -3.152 & 6.067 & $\begin{array}{ll}\text { No } & \text { significant } \\
\text { difference } & \end{array}$ \\
\hline NGO board - Civil society & 1.000 & -2.632 & 6.587 & $\begin{array}{ll}\text { No } & \text { significant } \\
\text { difference } & \end{array}$ \\
\hline NGO staff - Government & 1.000 & -2.510 & 6.710 & $\begin{array}{ll}\text { No } & \text { significant } \\
\text { difference } & \end{array}$ \\
\hline NGO staff - Civil society & 1.000 & -1.990 & 7.230 & $\begin{array}{ll}\text { No } & \text { significant } \\
\text { difference } & \end{array}$ \\
\hline Government - Civil society & 1.000 & -4.901 & 5.941 & $\begin{array}{ll}\text { No } & \text { significant } \\
\text { difference } & \end{array}$ \\
\hline
\end{tabular}

Source: Field survey, 2014

Following the analysis of table no. 2, the study found insignificant association between the respondents regarding their perception on environment of NGO. In the same way, the data also explored the relationship between the respondents regarding their response on 'value' of NGO. The data of table no. 3 shows that there was no significant difference between the respondents. NGO board vs. government or NGO's staff vs. civil society vs. beneficiaries were found no relations between them. The $\mathrm{P}$ value was found greater the .05 significant levels. It accepted the null hypothesis.

Table No. 4: Respondent wise multiple comparison of impact of NGOs

\begin{tabular}{|c|c|c|c|c|c|}
\hline \multirow[t]{2}{*}{ Description } & \multirow[t]{2}{*}{ Respondents types } & \multirow[t]{2}{*}{$\begin{array}{l}\text { P- } \\
\text { Values }\end{array}$} & \multicolumn{2}{|c|}{$\begin{array}{l}95 \% \text { confident } \\
\text { level }\end{array}$} & \multirow[t]{2}{*}{ Remarks } \\
\hline & & & $\begin{array}{l}\text { Lower } \\
\text { bound }\end{array}$ & $\begin{array}{l}\text { Upper } \\
\text { bound }\end{array}$ & \\
\hline \multirow{4}{*}{ : } & Beneficiaries - NGO board & 1.000 & -4.846 & 2.397 & $\begin{array}{l}\text { No significant } \\
\text { difference }\end{array}$ \\
\hline & Beneficiaries - NGO staff & 1.000 & -5.096 & 2.147 & $\begin{array}{l}\text { No significant } \\
\text { difference }\end{array}$ \\
\hline & Beneficiaries - Government & 1.000 & -3.931 & 6.536 & $\begin{array}{l}\text { No significant } \\
\text { difference }\end{array}$ \\
\hline & Beneficiaries - Civil society & 1.000 & -4.051 & 6.416 & $\begin{array}{l}\text { No significant } \\
\text { difference }\end{array}$ \\
\hline
\end{tabular}


ISSN: 2362-1303 (Paper) | eISSN: 2362-1311(Online)

JOURNAL OF ADVANCED ACADEMIC RESEARCH (JAAR)

\begin{tabular}{|l|l|l|l|l|l|}
\hline & NGO board - NGO staff & 1.000 & -5.047 & 4.547 & $\begin{array}{l}\text { No significant } \\
\text { difference }\end{array}$ \\
\cline { 2 - 6 } & NGO board - Government & 1.000 & -3.579 & 8.633 & $\begin{array}{l}\text { No significant } \\
\text { difference }\end{array}$ \\
\cline { 2 - 6 } & NGO board - Civil society & 1.000 & -3.699 & 8.513 & $\begin{array}{l}\text { No significant } \\
\text { difference }\end{array}$ \\
\cline { 2 - 6 } & NGO staff - Government & 1.000 & -3.329 & 8.883 & $\begin{array}{l}\text { No significant } \\
\text { difference }\end{array}$ \\
\cline { 2 - 6 } & NGO staff - Civil society & 1.000 & -3.449 & 8.763 & $\begin{array}{l}\text { No significant } \\
\text { difference }\end{array}$ \\
\cline { 2 - 6 } & Government - Civil society & 1.000 & -7.300 & 7.060 & $\begin{array}{l}\text { No significant } \\
\text { difference }\end{array}$ \\
\hline
\end{tabular}

Source: Field survey, 2014

Impact is known as the output of NGO. The study also evaluated the impact of NGO in the Karnali Zone. The analysis of survey data presented in table no. 4 shows that there was no significant difference between the respondents regarding the impact of NGO. It is interesting that the $\mathrm{P}$ value of each relation was found equal $(\mathrm{P}=1.000)$ which is greater than .05 . The result accepted there was no significant difference between the respondents.

Table no. 5: Respondent wise Sub group of main elements of NGOs

\begin{tabular}{|c|c|c|c|c|}
\hline $\begin{array}{c}\text { Main } \\
\text { Element }\end{array}$ & Sub-Elements & F Value & P-Values & Remarks \\
\hline \multirow{7}{*}{ 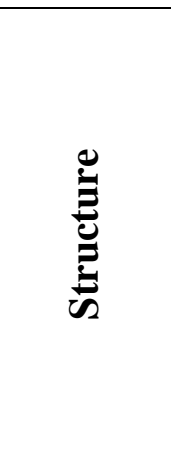 } & & 3.582 & 0.007 & Significant \\
\hline & Breadth of citizen Participation & 3.881 & .004 & Significant \\
\hline & Depth of citizen participation & 3.964 & .004 & Significant \\
\hline & $\begin{array}{l}\text { Diversity of civil society } \\
\text { participants }\end{array}$ & 2.132 & .076 & Insignificant \\
\hline & Resources & 3.177 & .013 & Significant \\
\hline & Level of organization & .305 & .875 & Insignificant \\
\hline & Inter relations & 2.740 & .028 & Significant \\
\hline \multirow{8}{*}{ 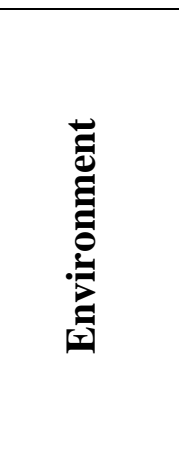 } & & 0.941 & 0.44 & Insignificant \\
\hline & Political context & 2.037 & .088 & Insignificant \\
\hline & Basic freedom \& rights & 2.134 & .075 & Insignificant \\
\hline & Socio-economic context & 1.144 & .335 & Insignificant \\
\hline & Socio-cultural context & .005 & 1.000 & Insignificant \\
\hline & Private sector civil society & 1.960 & .099 & Insignificant \\
\hline & Legal environment & .700 & .592 & Insignificant \\
\hline & State civil society relation & .782 & .537 & Insignificant \\
\hline$\dot{\nu}^{\infty} \stackrel{0}{\Xi} n$ & & 0.977 & 0.420 & Insignificant \\
\hline
\end{tabular}


ISSN: 2362-1303 (Paper) | eISSN: 2362-1311(Online)

JOURNAL OF ADVANCED ACADEMIC RESEARCH (JAAR)

\begin{tabular}{|c|c|c|c|c|}
\hline & Democracy & .490 & .743 & Insignificant \\
\hline & Transparency & 1.884 & .112 & Insignificant \\
\hline & Tolerance & .770 & .545 & Insignificant \\
\hline & Non-violence & 1.265 & .283 & Insignificant \\
\hline & Environmental sustainability & 1.377 & .240 & Insignificant \\
\hline & Poverty eradication & .749 & .559 & Insignificant \\
\hline & Gender equity & 1.195 & .312 & Insignificant \\
\hline \multirow{6}{*}{$\begin{array}{l}\bar{\Xi} \\
\stackrel{\Xi}{\Xi} \\
\stackrel{\Xi}{\mid}\end{array}$} & & 0.829 & 0.507 & Insignificant \\
\hline & Holding state \& private sector & 1.279 & .277 & Insignificant \\
\hline & Influencing public policy & .700 & .592 & Insignificant \\
\hline & Responding to social interest & .151 & .963 & Insignificant \\
\hline & Empowering citizens & 1.372 & .242 & Insignificant \\
\hline & Building social capital & 1.596 & .174 & Insignificant \\
\hline
\end{tabular}

Source: Field survey, 2014

From the above table no 5 under the structure, there are six components. Out of six, four components observed significant. Breadth of citizen participants $\mathrm{F}$ value is 3.881 and $\mathrm{P}$-value is 0.004, Depth of citizen participation F value is 3.964 and P-value is 0.004 , Resources $F$ value is 3.177 and $\mathrm{P}$-value is 0.013 and inter relations $\mathrm{F}$ value is 2.74 and $\mathrm{P}$-value is 0.028 Out of six two components are insignificant, diversity of civil society participants $\mathrm{F}$ value is 2.132 and $\mathrm{P}$-value is 0.076 and level of organization $\mathrm{F}$ value is 0.305 and $\mathrm{P}$-value is 0.875

And other three main components environment, values and impact of the nineteen components are not significantly difference observed within respondents.

\section{Discussion}

The study found the significant difference on structure of NGO from the perceptual analysis of respondents. Under the structure of NGO, there was significant difference on the depth of citizen participation, mobilization of resources and inter relations which determines the social status of NGO and its effect on development. The beneficiaries, civil society and NGOs staff had different perception on volunteering, charitable giving, NGO membership, collective action under and the financial, human and technical resources as well as level of communication and cooperation of NGOs in the districts. Many previous literatures has accepted NGO as a development partners. Lenihan, Eoghan Walsh and Helena has stated that NGOs are significant players in the development field (2006, p. 422). In the Nepalese context, the role of NGOs and Civil Societies are still service and development oriented. Civil societies play important roles in the changing of individuals' lives by bringing together diverse groups of people to solve social problems (Bhandari, 2014, p. 177). 
ISSN: 2362-1303 (Paper) | eISSN: 2362-1311(Online)

JOURNAL OF ADVANCED ACADEMIC RESEARCH (JAAR)

January 2015

From the perspective of respondents of all five districts, there was no significant difference on environment, values and impact of NGO. Environment wise, there was no association in political context, basic freedom \& rights, socio-economic context, legal environment and state civil society relationship in these study areas. Though, it was acceptable that all the NGOs of different districts were providing their services to the community. According to Yap, Nonita also, there are NGOs which define their mandate as helping to remove the stumbling blocks to development: some pursue this objective through the delivery of relief and social welfare services; others do it by helping to organize communities or sectors (1989/1990, p. 77).

Values of NGO talk about the democracy, transparency, tolerance, non-violence, environmental sustainability, poverty reduction and gender equity. All these variables were insignificant with the perception of respondents in Karnali zone. There was no relation between the respondents but independently all these factors were working in the study areas. The previous study showed that in modem development discourse, one area that has gained considerable currency has been the impact delivered by NGOs, mainly because their work is understood to have direct and obvious effects on the lives of poor and marginalized people (Linda Kelly, 2004, p. 696). The NGO sector is hugely diverse, ranging from small CBOs dealing with local community issues to larger, nationally based NGOs, which mostly address social or economic needs (Mercer, 1999, p. 249).

Impact of NGO explained about the holding state \& private sector, influencing public policy, responding to social interest, empowering citizens and building social capital in this study. These factors were also found insignificant differences from the perspective of respondents. The contributions of NGO in these sectors were found meaningful in their particular context and it was also reported in the previous studies. Nusrat Jahan Chowdhury has stated that both national and international policy-making institutions have acknowledged the contribution of NGOs in alleviating poverty, through empowering the poor and continuing to support their endeavors (Chowdhury, 2008, p. 117). Characteristics of the Process of Development with Equity it is important to appreciate the full significance of the point that the right to development associates development with equity and justice (Sengupta, 1999). NGOs have done much to address the needs and issues of the 'poor across the world. However, much remains to be done with regard to understanding the effects that NGOs and their multiple approaches and agendas have on wider sociological processes such as the building of social capital and social organizing (Abom, 2004, p. 342).

Presence of NGO also plays the role to create the positive relationship between the different key stakeholders. From the study showed that there was no association between the various activities of NGO in Karnali zone from the respondents perspective though independently their status was meaningful. Lawrence T. Woods showed the important of NGO by stating that the ability to 
ISSN: 2362-1303 (Paper) | eISSN: 2362-1311(Online)

JOURNAL OF ADVANCED ACADEMIC RESEARCH (JAAR)

January 2015

foster mutual understanding among peoples and states and between people and states is considered vital by most NGOs (1995, p. 824).

\section{Conclusion}

The study was focused to identify the status; structure, environment, value and impact of NGOs in Karnali zone with the perspective of different respondents NGO board, NGO staff, Beneficiaries, Government agencies and Civil Societies. The findings showed that there was significant difference in structure. The perspective of beneficiaries and civil society, NGO board and civil society had different perception in breadth and depth of citizen participation; inter relation and resources of the NGOs. It could be assumed that because of the geographical differences, involvement of human resources, basic infrastructure, access on communication and technologies and perception on NGOs activities are the major factors which made the perceptual difference among the respondents. Similarly, the findings showed that the rest major three elements; environment, values and impact had no significant difference. From the respondents' perspective, the status of these three elements was similar in all five districts. Normally, it could be observed that the contribution of NGO in promotion of political awareness, transparency of their work and empowering citizenship were more or less in the same level in all five district so response of participants became similar. The study found the similar response of respondents in environment, values and impact of NGO so it is necessary to identify the locally reliable and related indicators of NGO to assess the NGO's status and their performance.

\section{References}

Abom, B. (2004, April). Social Capital, NGOs, and Development: A Guatemalan Case Study. Development in Practice, 14(3), 42-353.

Bhandari, M. (2014). Civil Society and Non-Governmental Organizations (NGOs) Movements in Nepal in terms of Social Transformation. Pacific Journal of Science and Technology, 177-189.

Chowdhury, N. J. (2008). A Journey towards Development: The Impact of Local NGO Programmes on Women Living in the Char Lands of Bangladesh. Development in Practice, 117-124.

Dhakal, T. N. (2007). Challenges of Civil Society Governance in Nepal. JOAAG Vol. 2 no 1, 65 66.

Ingdal, A. S. (2007). A Discussion Paper on Donor Best Practices Towards NGOs in Nepal. Norwegian Agency for Development Cooperation, Oslo, Norway.

Lenihan, E. W. (2006, August). Accountability and Effectiveness of NGOs: Adapting Business Tools Successfully. Development in Practice, 16(5), 412-424. 
ISSN: 2362-1303 (Paper) | eISSN: 2362-1311(Online)

JOURNAL OF ADVANCED ACADEMIC RESEARCH (JAAR)

Linda Kelly, P. K. (2004). Impact Measurement for NGOs: Experiences from India and Sri Lanka. Development in Practice, 696-702.

Lund, R. N. (2012). Review of NGO performance research published in academic journals between 1996 and 2008. Adolescent Health Research, Unit, University of Cape, Town, Cape Town, South Africa.

Mercer, C. (1999). Reconceptualizing State-Society Relations in Tanzania: Are NGOs 'Making a Difference'? Wiley, 247-258.

Sengupta, A. (1999). The Right to Development as a Human Right.

TUSALEM, R. F. (2007, June). Boon or a Bane? The Role of Civil Society in Third-and FourthWave Democracies. International Political Science Review / Revue internationale de science politique, Vol.28, No. 3 (Jun., 2007), pp. 361-386, 28(3), pp.361-386.

Woods, L. T. (1995, September). Learning from NGO Proponents of Asia-Pacific Regionalism: Success and Its Lessons. Asian Survey, 35(9), 812-827.

Yap, N. (1989/1990, Winter). CouncilNGOs and Sustainable Development. International Journal,, 45(1), 75-105. 